\title{
Seismic imaging of the Formosa Ridge cold seep site offshore of southwestern Taiwan
}

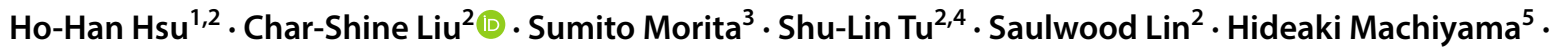 \\ Wataru Azuma ${ }^{6}$. Chia-Yen $\mathrm{Ku}^{4}$. Song-Chuen $\mathrm{Chen}^{7}$
}

Received: 2 August 2017 / Accepted: 7 December 2017 / Published online: 16 December 2017

(c) The Author(s) 2017. This article is an open access publication

\begin{abstract}
Multi-scale reflection seismic data, from deep-penetration to high-resolution, have been analyzed and integrated with nearsurface geophysical and geochemical data to investigate the structures and gas hydrate system of the Formosa Ridge offshore of southwestern Taiwan. In 2007, dense and large chemosynthetic communities were discovered on top of the Formosa Ridge at water depth of $1125 \mathrm{~m}$ by the ROV Hyper-Dolphin. A continuous and strong BSR has been observed on seismic profiles from 300 to $500 \mathrm{~ms}$ two-way-travel-time below the seafloor of this ridge. Sedimentary strata of the Formosa Ridge are generally flat lying which suggests that this ridge was formed by submarine erosion processes of down-slope canyon development. In addition, some sediment waves and mass wasting features are present on the ridge. Beneath the cold seep site, a vertical blanking zone, or seismic chimney, is clearly observed on seismic profiles, and it is interpreted to be a fluid conduit. A thick low velocity zone beneath BSR suggests the presence of a gas reservoir there. This "gas reservoir" is shallower than the surrounding canyon floors along the ridge; therefore as warm methane-rich fluids inside the ridge migrate upward, sulfate carried by cold sea water can flow into the fluid system from both flanks of the ridge. This process may drive a fluid circulation system and the active cold seep site which emits both hydrogen sulfide and methane to feed the chemosynthetic communities.
\end{abstract}

Keywords Gas hydrates · Cold seep · Fluid migration · Reflection seismic · Formosa Ridge

\section{Introduction}

In the area offshore of southwestern (SW) Taiwan where an active accretionary complex meets with the passive China continental margin, widely distributed bottom simulating reflectors (BSR) have been observed, and are mostly concentrated underneath the slope ridges of the passive margin and anticlinal ridges in the active margin (Liu et al. 2006; Lin et al. 2009, 2011; Matsumoto et al. 2011; Liao et al. 2014). Because BSR are important indicators for the presence of gas hydrate, it is suggested that methane hydrate occurs broadly within the thick Quaternary marine sediments here. Previous geochemical investigations in the SW Taiwan offshore area show that high methane concentration anomalies $(>1000 \mathrm{~nL} / \mathrm{L})$ in the dissolved gases of bottom water are detected at some locations (Chuang et al. 2006, 2013; Yang et al. 2006), and in the pore fluids of cored samples at many coring sites (Chuang et al. 2006, 2010, 2013). The sulfate reduction depths (Borowski et al. 1999) are as shallow as 30-300 cm at those sites (Lin et al. 2006; Chuang 
et al. 2013). Many of the sites revealing geochemical anomalies suggest that high methane anomalies could be caused by extrusion of free methane gases underneath (Yang et al. 2004; Chuang et al. 2010; Lim et al. 2011).

Fluid activities are evident from various features such as mud volcanoes, vigorous vents and seismic wipe outs observed on sub-bottom $(3.5 \mathrm{kHz}$ and chirp sonar) and seismic reflection profile data (Chiu et al. 2006; Chen et al. 2012, 2014; Klaucke et al. 2016). Authigenic carbonates with highly depleted carbon isotope values and authigenic pyrites have been found in the cored seafloor sediments, indicating that there are methane carrying seeps in this area (Huang et al. 2006; Tong et al. 2013; Han et al. 2014; Guan et al. 2016), deep-towed camera images also confirm wide spread authigenic carbonates on the seafloor with some chemosynthetic communities composed of bacteria mats and clams at some of the suspected cold seep sites (Lin et al. 2007a; Wang and Liu 2009; Berndt 2013; Yang et al. 2016).

In March 2007, a Taiwan-Japan collaborative research cruise was conducted in the area offshore SW Taiwan aiming to examine the formation processes of mud volcanoes and cold seeps. Direct observation and sampling of sediments, rocks, chemosynthetic organisms, water, and gases at several sites were carried out using $3000 \mathrm{~m}$-class ROV (remotely operated vehicle) Hyper-Dolphin. High resolution geophysical surveys including swath bathymetry mapping, side scan sonar imaging, and single-channel seismic reflection profiling were also conducted around the diving sites (Morita et al. 2009). One of the most significant discoveries of this cruise is the observation and sampling of an unusual chemosynthetic community on top of a slope ridge, named Formosa Ridge (Liu et al. 2008), located in the passive China continental margin about $100 \mathrm{~km}$ southwest of Taiwan (Machiyama et al. 2007; Lin et al. 2007a, b). This very densely populated chemosynthetic community is characterized by two dominated benthic animals: a deep sea mussel (Bathymodiolus cf. platifrons), and a galatheid shrimp (Shinkai cf. cronieri). These species are also dominated in the hydrothermal vent communities in the Okinawa Trough and many places elsewhere in the world (Fujikura et al. 2007; Yang et al. 2016), indicating that hydrogen sulfide and methane might dominate this environment (Lin et al. 2007b).

Comparing to other over 30 cold seeps discovered on the northern slope of the South China Sea, the Formosa Ridge is the only known active gas seepage (Feng and Chen 2015; Feng et al. 2015), as other sites became inactive before 11.5 Ka BP (Suess et al. 2005; Tong et al. 2013; Han et al. 2014). As a result, the Formosa Ridge became a hot spot to study biogeochemical processes (Feng and Chen 2015; Feng et al. 2015; Guan et al. 2016), fluid migration and heat flow activity (Chen et al. 2012, 2014; Liao et al. 2014). While these data indicate that fluid circulation systems occur on the crest of the Formosa Ridge, which provide methane to the seafloor to support active chemosynthetic biologic communities, little has been published on the geologic controls of this cold seep site (Liu et al. 2008; Berndt 2013; Berndt et al. 2014; Liao et al. 2014; Swidinsky et al. 2014).

In order to better understand the geological controls of this cold seep site, characteristics of the gas hydrate and free gas reservoirs underneath, and possible fluid migration paths, we have compiled a detailed bathymetry map and examined all the seismic data available over and around the Formosa Ridge, including high-resolution single channel seismic data collected by the R/V Natsushima in 2007, R/V Ocean Researcher I from 2004 to 2007, and R/V Marcs G. Langseth in 2009 (Table 1). We review the geological setting of the Formosa Ridge and the morpho-tectonic characters of the study area by multi-scale seismic analyses first, then present the seismic images from both high-resolution to deep
Table 1 Seismic data acquisition specifications for cruise expedition data shown in this study

\begin{tabular}{llll}
\hline Acquisition vessel & Natsushima & Ocean researcher I & Marcus G. Langseth \\
Cruise & NT07-05 & MCS754 & MGL0905 \\
Year & 2007 & 2005 & 2009 \\
Category & High-resolution & Deep seismic & Large-offset deep seismic \\
Source & 2 air guns & 3 air guns & Air gun array (40 guns) \\
Source volume (in. $\left.{ }^{3}\right)$ & $40 \times 2$ & $275+150+120$ & 6600 \\
Air pressure (psi) & 2000 & 2000 & 2000 \\
Shot interval (m) & 12.5 & $\sim 25$ & 50 \\
Source depth (m) & $\sim 1.5$ & $3-5$ & 8 \\
No. of channel (s) & 1 & 24 & 468 \\
Channel interval & N/A & $12.5 \mathrm{~m}$ & $12.5 \mathrm{~m}$ \\
Cable lead + Max. offset (M) & $135+47$ & $130+300$ & $185+5850$ \\
Streamer depth (m) & $\sim 2$ & $3-5$ & 9 \\
Sample rate (ms) & 1 & 2 & 2 \\
Recording length (s) & 4 & 6 & 15 \\
\hline
\end{tabular}


penetration seismic profiles. Seismic investigation reveals an active fluid conduit beneath the cold seep site, and the ridge geometry enables the formation of a fluid circulation system which may explain this cold seep environment.

\section{Morphotectonic setting}

The Luzon subduction system encroaches on the passive China continental margin in the area offshore SW Taiwan (Liu et al. 1997, 2004; Lin et al. 2009a). A deformation front extending NW-ward from the northern edge of the Manila Trench to the foot of the continental slope separates the offshore area of SW Taiwan into distinctive fold-and-thrust structures of the convergent zone in active margin and horst-and-graben structures of the passive margin (Fig. 1). Reflection seismic data reveal a complex system of folds, faults, mud diapirs, sedimentary basins, and submarine channels in the area (Liu et al. 1997, 2004; Lin et al. 2008, 2009b, Hsu et al. 2013).

Morphologically, both the passive China continental slope and the convergent submarine Taiwan accretionary wedge are dominated by submarine canyons and ridges (Fig. 2), however, the ridges are formed by very different mechanisms on either side the deformation front. In the accretionary wedge province to the east of the deformation front, the ridges were formed mostly by fold-bend faults or, in the near shore area, by diapirism (Liu et al. 1997; Lin et al. 2008, 2009b, Hsu et al. 2013). On the other hand, most of the ridges on the China continental slopes were formed by the submarine erosion processes, i.e. they were formed by submarine canyon down-slope cuttings on the surface of the China continental slope. These submarine canyons were mostly developed in the upper slope area near the shelf break.
Fig. 1 Tectonic setting of southwestern Taiwan offshore area. Red line with teeth shows the location of the deformation front which separates the convergent submarine Taiwan accretionary wedge to the east from the passive China continental margin to the west. Yellow circle indicate the location of the Formosa Ridge. Inlet: A $3 \mathrm{D}$ view of the fold-and-thrust structures in the accretionary wedge province versus normal fault structures of the passive continental margin offshore southwestern Taiwan

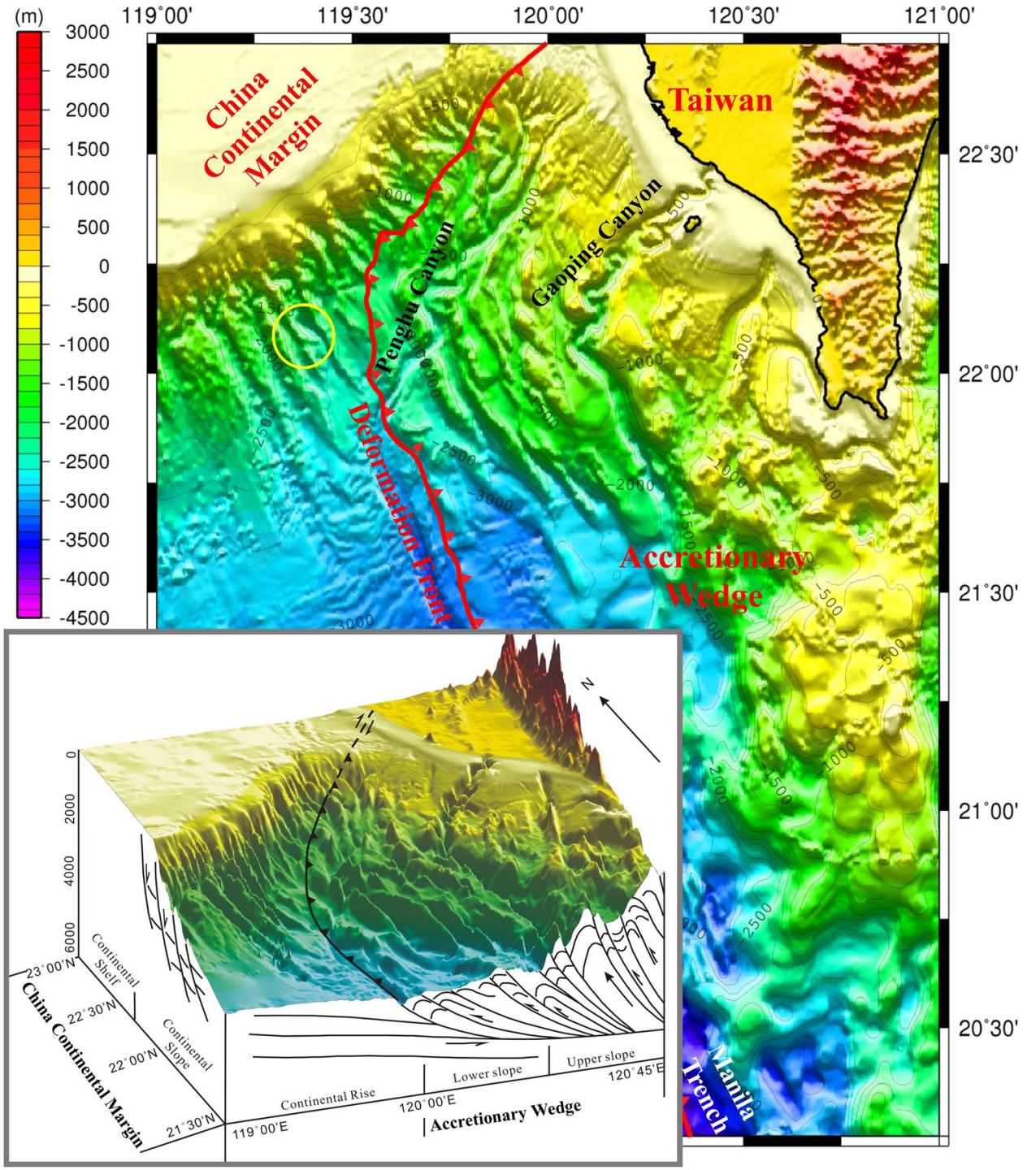




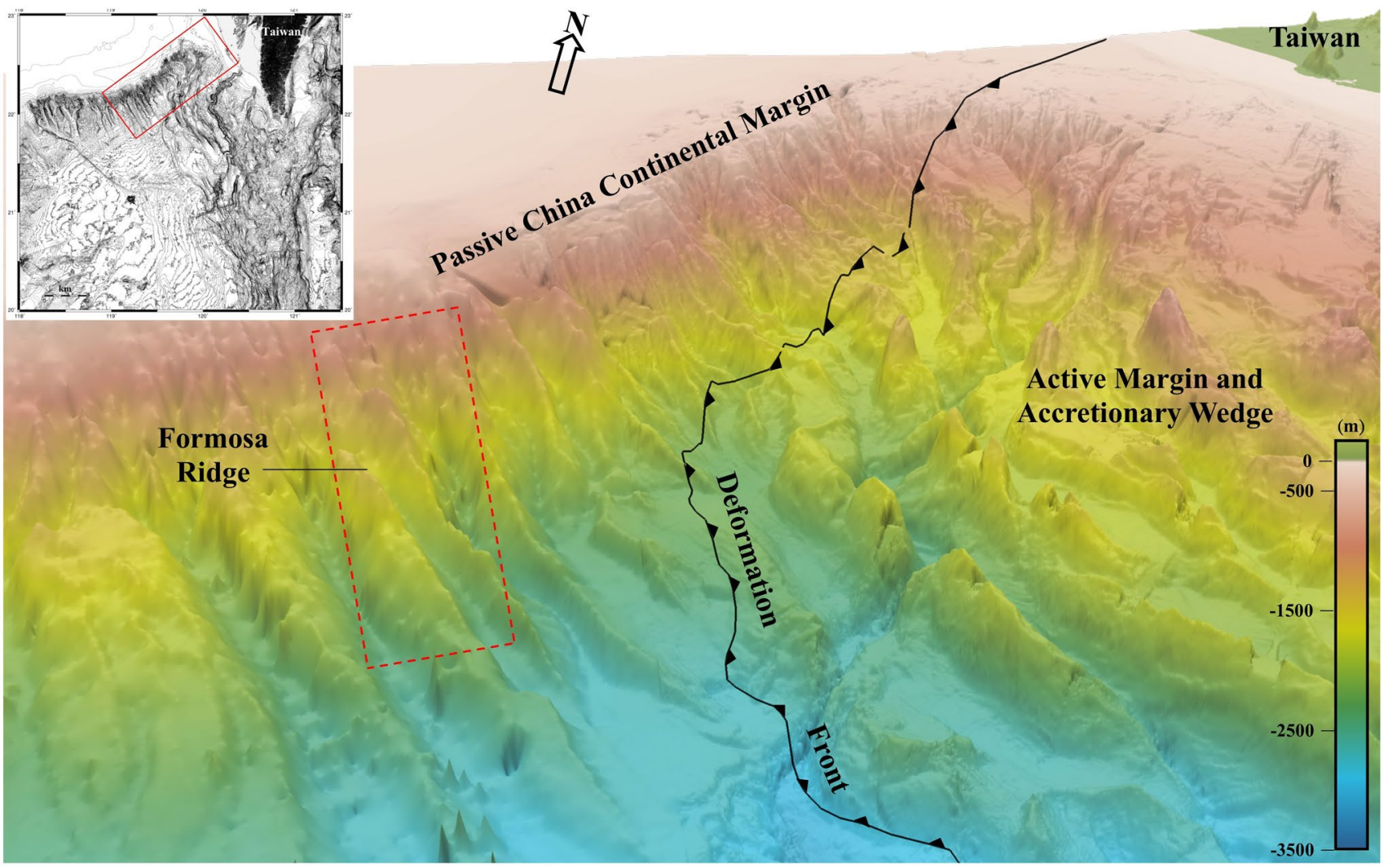

Fig. 2 Shaded seafloor relief map of the China continental margin and the adjacent accretionary wedge offshore southwestern Taiwan. A deformation front separates the offshore area of SW Taiwan into the active margin and the passive margin. The red dashed box shows the area of the multibeam bathymetry data presented in Fig. 3. Inset: Index map of the area shown
The Formosa Ridge lies to the west of the deformation front in the mid-slope region of the passive China continental slope (Fig. 2). Swath bathymetry data of this ridge and its adjacent area have been collected by the R/V Natsushima using a Reson SeaBat 8160 system providing both swath bathymetry (Fig. 3) and sidescan images. There are two NNW-SSE trending ridges in the multibeam survey area, the western ridge is the Formosa Ridge where an active cold seep site is located (Lin et al. 2007a, b; Morita et al. 2009; Feng and Chen 2015; Feng et al. 2015; Guan et al. 2016). The Formosa Ridge does not start from the upper continental slope as there is a disconnection formed across its northern end. It extends from mid-slope to the South China Sea seafloor near the Manila Trench, with a total length of about $45 \mathrm{~km}$. The Formosa Ridge presents two peaks along the ridge crest. The northern peak has a water depth of about $1088 \mathrm{~m}$ while the southern peak (where the cold seep and ROV diving site $\mathrm{F}$ is located) has a water depth of about $1125 \mathrm{~m}$.

\section{Seismic investigation}

Multichannel seismic reflection surveys in the China continental margin offshore SW Taiwan have been conducted using R/V Ocean Researcher I from 2003 to 2015 as part of the gas hydrate investigation program of the Central Geological Survey, MOEA, Taiwan. Table 1 and Fig. 4 show the specification and distribution of seismic profiles in the Formosa Ridge area. Liu et al. (2006) first reported the existence of a strong and continuous BSR below the seafloor of the Formosa Ridge. Then during the 2007 R/V Natsushima NT07-05 cruise, high-resolution single channel seismic reflection surveys were conducted at each of the ROV diving sites to provide sub-strata images and structural constraints of the diving sites (JAMSTEC and TNCOR 2007; Morita et al. 2009). The high-resolution seismic profile images reveal details of the shallow sedimentary strata well, however, little information could be obtained below the BSR. Then in 2009 during 
Fig. 3 Morphology of the Formosa Ridge revealed by the swath bathymetry data. $N P$ northern peak. $S P$ southern peak (where cold seep site is located). The northern peak has a water depth of about $1088 \mathrm{~m}$ and the southern peak where the cold seep is located has a water depth of about $1125 \mathrm{~m}$. See Fig. 2 for map location

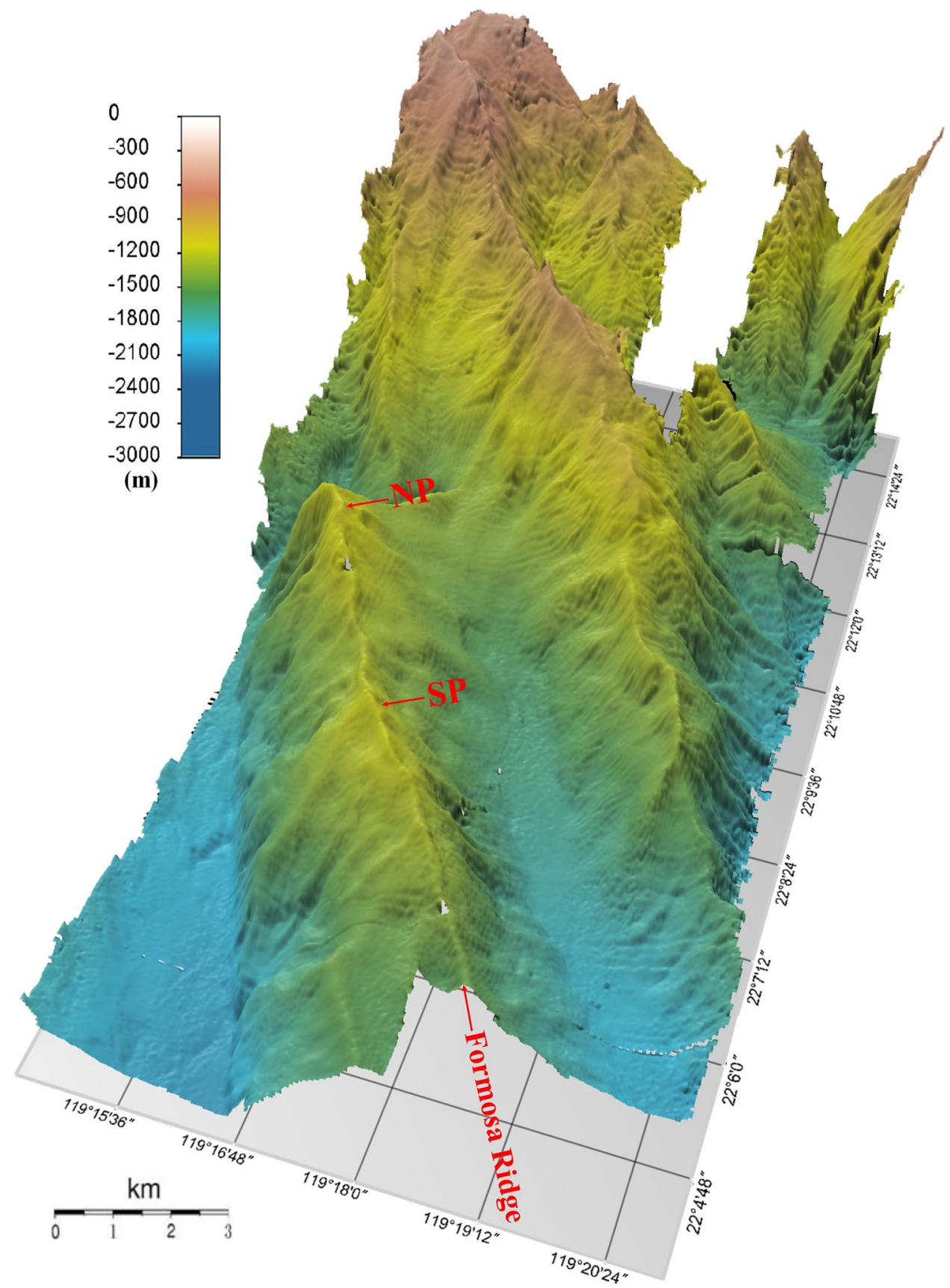

the TAIGER marine seismic survey using the U.S. R/V Marcus G. Langseth, deep seismic reflection data were collected along two transects across the Formosa Ridge. These two large-offset (using a 6-km long streamer) seismic profile data (Table 1) provide images on the deeper structures of the Formosa Ridge, they also enable us to derive velocity information for the gas hydrate bearing strata and the free gas zone beneath the BSR. In this section, we present our analysis of the seismic investigation.

\section{High-resolution seismic images}

The high-resolution single channel seismic reflection data were collected using the seismic data acquisition system described in Table 1. These seismic data were processed by Nippon Marine Enterprises (NME) technical staff onboard R/V Natsushima. Standard processing procedures were adopted that include trace editing, static shift, bandpass filtering, amplitude compensation, CMP sorting, 
Fig. 4 Seismic profile location map of the study area. Colored area shows where swath bathymetry data are available (Fig. 3), black thin lines are the seismic data collected by the R/V Ocean Researcher I, red lines annotated with line names are the seismic profiles shown in this paper. $N P$ north peak, $S P$ south peak. Bathymetry contour interval is $50 \mathrm{~m}$

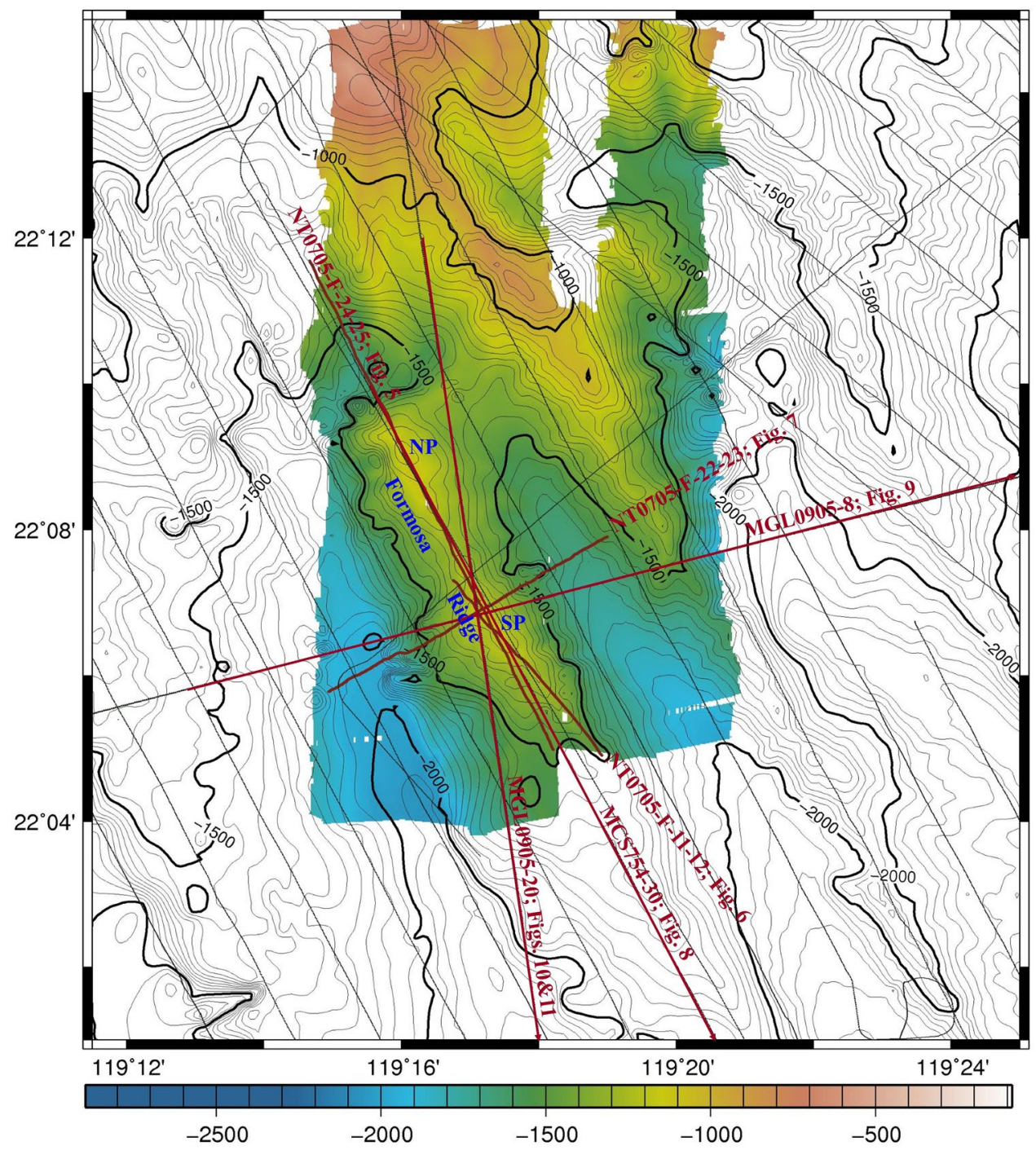

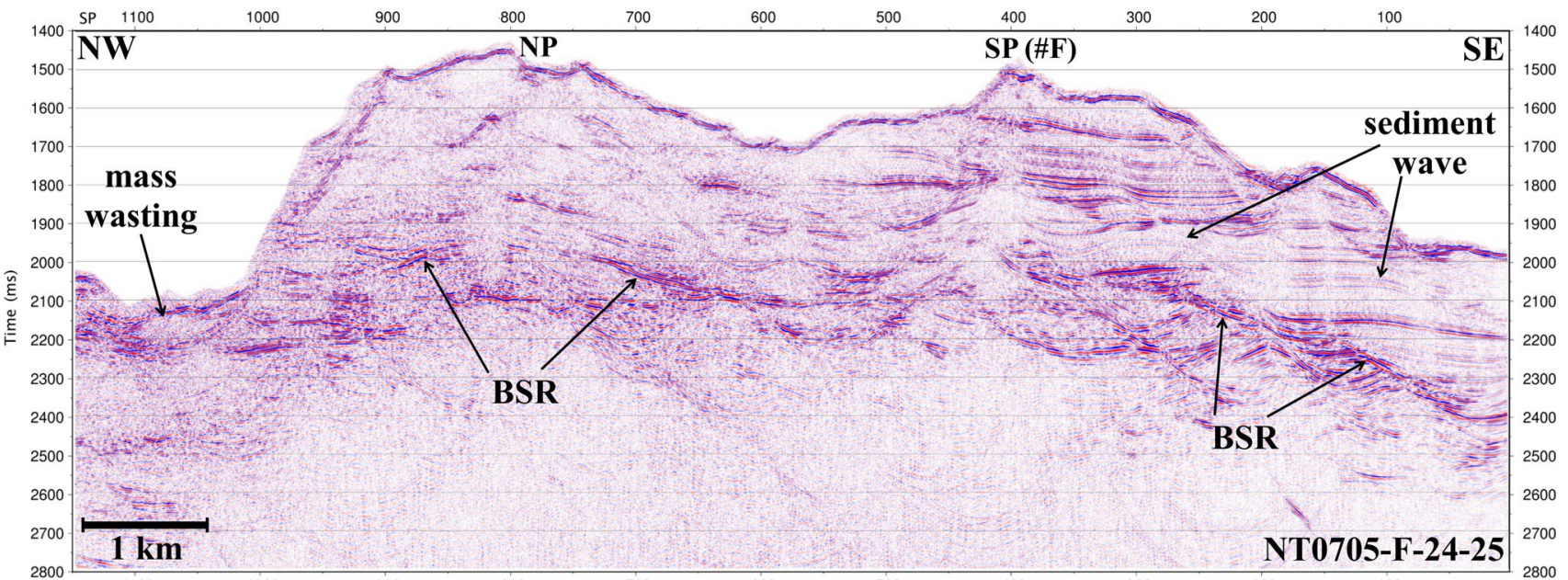

Fig. 5 Single channel seismic profile NT0705-F-24-25. This seismic profile runs along the axis of the Formosa Ridge (see Fig. 4 for profile location). $N P$ north peak. $S P(\# F)$ south peak where ROV diving site $\mathrm{F}$ is located 
Fig. 6 Single channel seismic profile NT0705-F-11-12. This seismic profile runs over the south peak of the Formosa Ridge (see Fig. 4 for profile location). SP (\#F) south peak where ROV diving site $\mathrm{F}$ is located

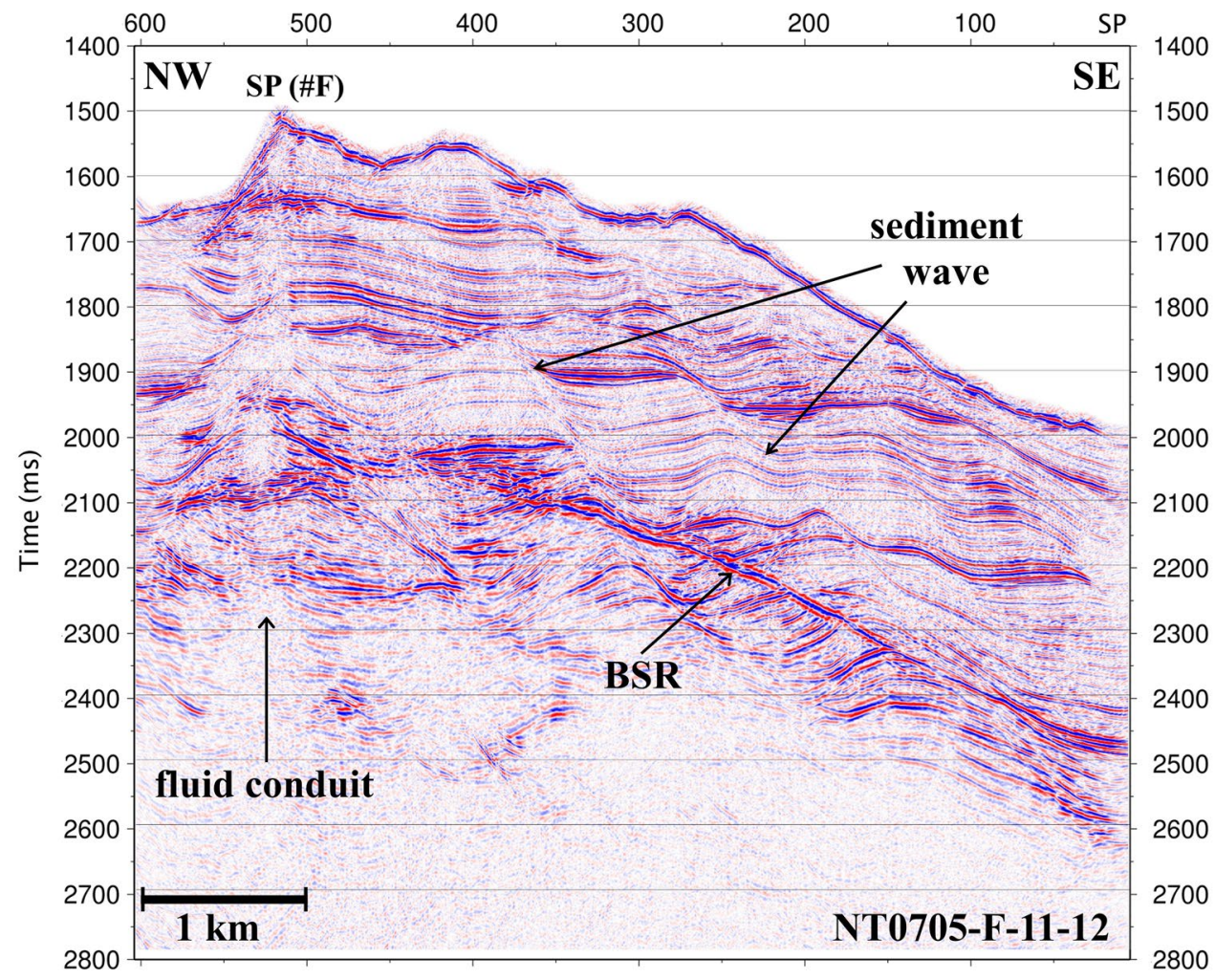

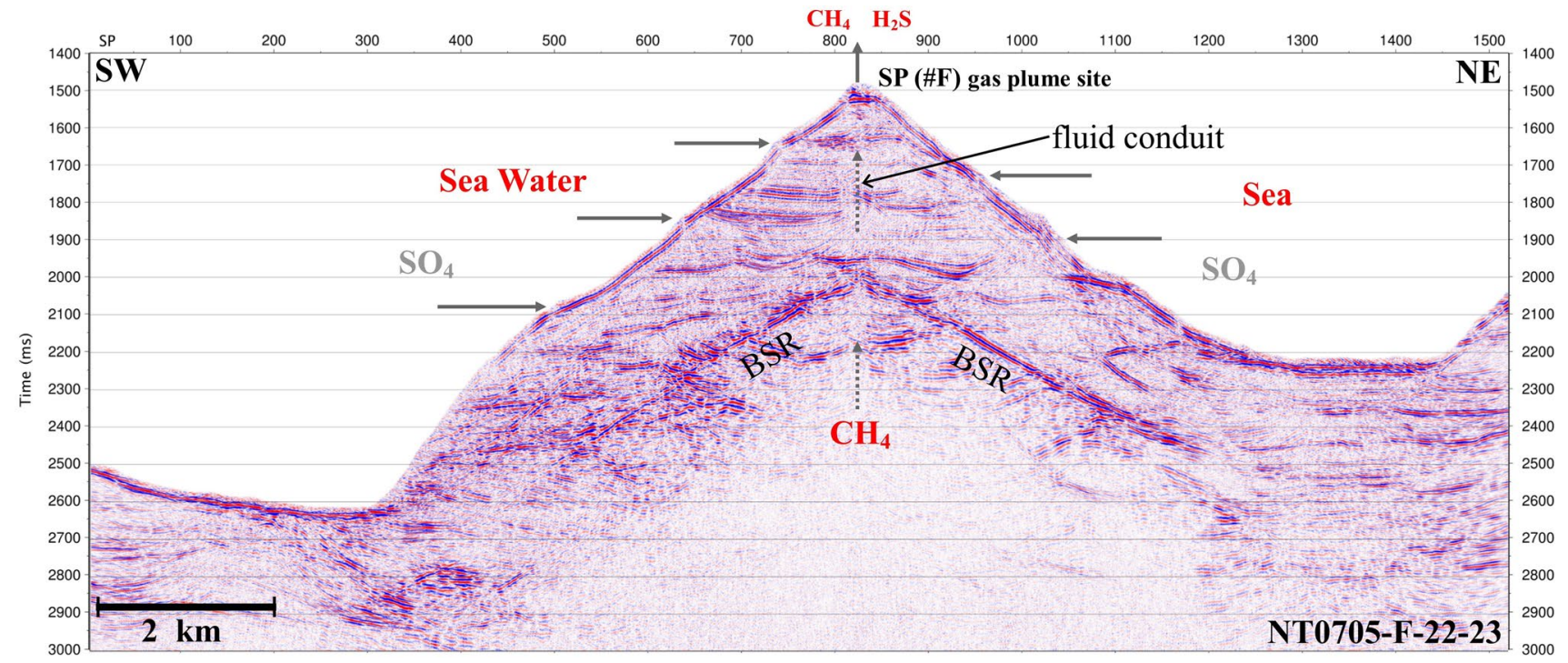

Fig. 7 Single channel seismic profile NT0705-F-22-23 and schematic diagram of fluid circulation model of the Formosa Ridge. This seismic profile runs across the Formosa Ridge near the cold seep site (see

and Stolt constant velocity migration (using $1500 \mathrm{~m} / \mathrm{s}$ velocity).

For the area around diving site $\mathrm{F}$ (the Formosa Ridge site), a total of 14 SCS profiles have been collected. Due to the proximity of many of these 14 seismic profiles, we present two along-ridge-axis profiles NT0705-F-24-25,
Fig. 4 for profile location). SP (\#F) south peak where ROV diving site $\mathrm{F}$ is located

NT0705-F-11-12 (Figs. 5, 6) and a cross-section NT0705F-22-23 (Fig. 7) as representative profiles (Fig. 4). Those three profiles are hereinafter referred to as F24-25, F11-12 and F22-23, respectively.

Profile F22-23 presents a cross-section of the southern Formosa Ridge (Fig. 7) where a well-developed BSR 
appears symmetrically about $400 \mathrm{~ms}$ below the ridge floor. This profile lies near the southern peak of the southern Formosa Ridge where the seep site is located. Sediment strata appear to be flat-lying above BSR; while below BSR, reflections appear to be concave downward (5-20 ms slower, depending on depth below BSR), probably due to pull down effect of gas charged sediment. A vertical bank zone right beneath the peak of the ridge that extends down to BSR may represent a vent structure that provides a conduit for upward fluid migration.

Seismic profile F24-25 is along-ridge-axis of the Formosa Ridge (Fig. 5). The two peaks on Formosa Ridge (Fig. 3) correspond with shot point around 400 (the southern peak, SP) and around 800 (the northern peak, NP). A submarine canyon lies at the northern end of the Formosa Ridge. A BSR can be observed about $400-500 \mathrm{~ms}$ below seafloor across most portion of the profile. The BSR is more prominent beneath the gentle southward-dipping slope of the ridge, and is disrupted beneath the peaks and beneath the trough. The sedimentary strata are generally flat lying under the southern part of the Formosa Ridge but appear slightly domed in the northern part of the ridge. Local deformation of the sedimentary strata, probably due to submarine mass wasting processes, can be observed in many parts of the profile. Seismic reflection signals are disrupted at several places, most noticeably underneath the southern peak where cold seep site lies, probably due to fluid venting activities. There are also bright (high-amplitude) reflections observed within the strata, another indication of gas charged strata in this region.

Seismic profiles F11-12 runs along the southern portion of the Formosa Ridge which reveals detailed sedimentary structures under the southern Formosa Ridge (Fig. 6). The known seep site is located at the peak of the southern ridge near shot point 525 on this profile. Ridge sediments show an about $200 \mathrm{~ms}$ thick subbottom unit which has internal structures indicative of large climbing sediment waves, and a very clear BSR is seen about $500 \mathrm{~ms}$ below seafloor. The BSR is disrupted below the southern peak area where short segments of strong reflections suggest gas accumulations. A vertical blank zone appears right below the southern peak of the Formosa Ridge, which indicates a fluid conduit containing gas charged sediments extends from below the BSR to the seafloor.

\section{Deep seismic images}

A 24-channel seismic reflection profile MCS754-30 (Table 1; Fig. 8) runs along the axis of the Formosa Ridge very close to the track of profile F24-25 (Fig. 4). A prominent BSR is observed almost continuously along the ridge at a depth of about $500 \mathrm{~ms}$ below seafloor, appears

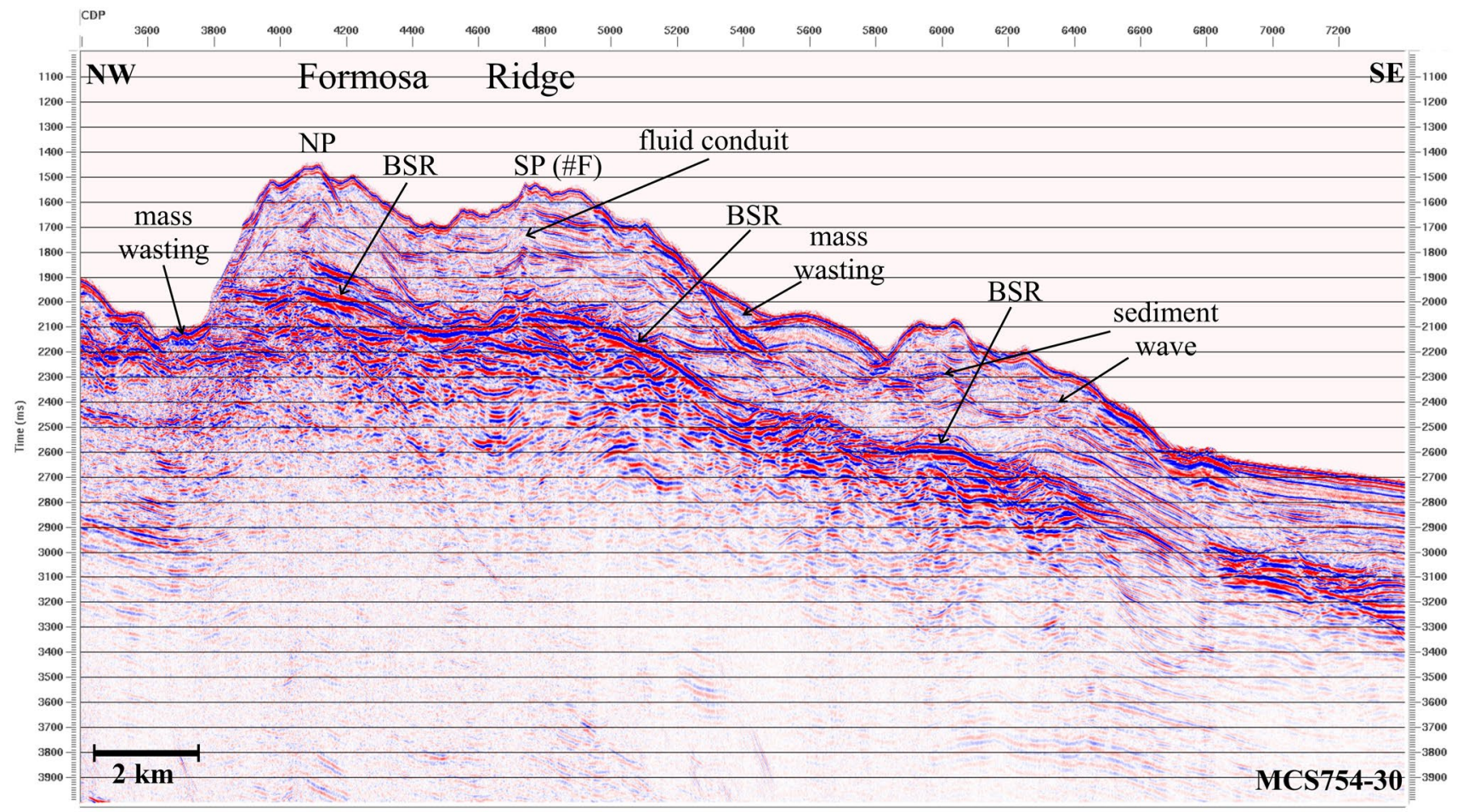

Fig. 8 24-channel seismic profile MCS754-30. This seismic profile runs along the axis of the Formosa Ridge (see Fig. 4 for profile location). Its northern half overlaps the seismic profile F24-25 (Fig. 5). NP north peak. SP (\#F) south peak where ROV diving site F is located 
disrupted only beneath the northern peak (NP). The strata are generally flat lying with variable dips in places where sediment wave features are observed. Local deformation of the sedimentary strata, probably due to submarine mass wasting processes, can be observed in many parts of the profile. Comparing to profile F24-25 (Fig. 5), high-amplitude deep reflections below BSR are much clear on this profile. The blanking and disruptions in reflector continuity beneath the southern peak can be traced from seafloor down to $1 \mathrm{~s}$ two-way-travel-time (TWT) below the seafloor, suggesting a deep gas source. Flat lying old sedimentary strata can be observed more clearly on deep seismic reflection profile MGL0905-8 (Fig. 9). This roughly E-W trending seismic profile runs across a series of slope ridges and reveals that BSR exists below all the slope ridges on the passive China continental slope. BSR is especially strong below the Formosa Ridge where sediment strata are flat lying above BSR while dip toward the center of the ridge below BSR, similar to what has been observed on profile F22-23 (Fig. 7). A vertical zone of disturbance lies beneath the southern peak of the Formosa Ridge, extends over $1 \mathrm{~s}$ TWT down from the seafloor to the inner portion of the ridge, suggests a conduit for gas migration. Deep reflection events below $3.2 \mathrm{~s}$ TWT show large amplitude variations along the profile. The very weak deep reflection zones appear to lie beneath where strong BSRs are present, suggesting that gas-charged sediment beneath BSR may have attenuated seismic energy.

Seismic profile MGL0905-20 runs across the Formosa Ridge obliquely (Fig. 4) but intercepts other seismic profiles presented previously at the southern peak of the ridge. Seismic image of this profile shows clear reflections both above and below the BSR along this profile (Fig. 10). Deep seaward dipping reflections are easily identifiable except below where BSR is strong. Sedimentary structures and faults are clear, so does the fluid conduit beneath the cold seep at the southern peak.

\section{Depth section and seismic velocity model}

We have performed pre-stack depth migration (PSDM) processing on the Formosa Ridge section of the MGL090520 profile data, the resultant depth section is shown in Fig. 11a, and the corresponding velocity model derived from the PSDM is shown in Fig. 11b. Comparing Fig. 11a with Fig. 10 (i.e., PSDM section vs. post-stack time migration section), the main seismic characters are similar, but the PSDM section gives an image with true geometry of space from TWT depth to true depth. The fluid conduit feature extends vertically at least $1500 \mathrm{~m}$ beneath the southern peak cold seep site. The velocity model shows clearly that there is a high velocity layer right above BSR and that there are low

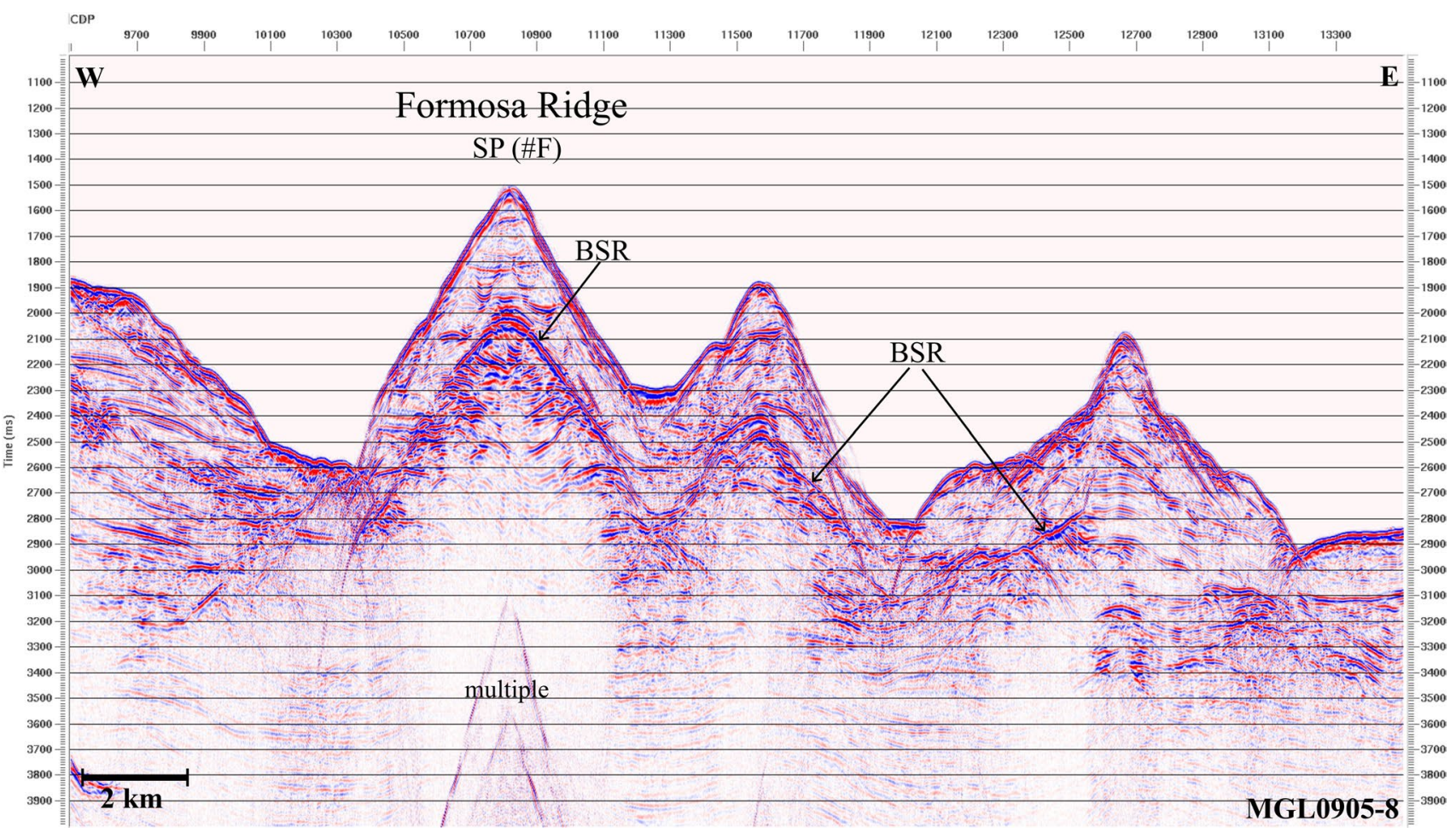

Fig. 9 Large-offset seismic reflection profile MGL0905-8. This seismic profile runs across the Formosa Ridge near the cold seep site (see Fig. 4 for profile location). $S P(\# F)$ south peak where ROV diving site $\mathrm{F}$ is located 


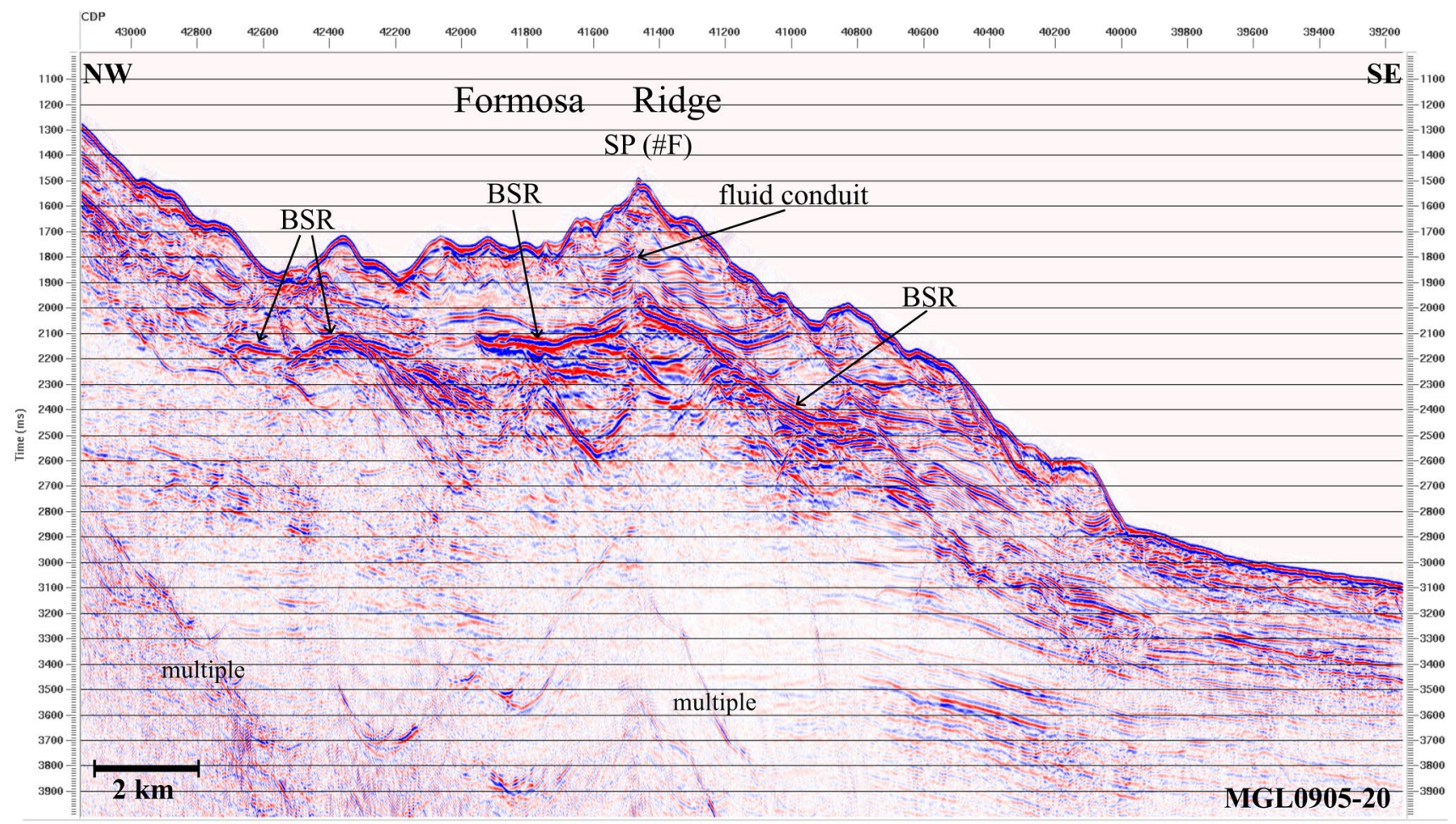

Fig. 10 Post-stack time migration section of seismic reflection profile MGL0905-20. This profile runs across the Formosa Ridge obliquely (see Fig. 4 for profile location). $S P(\# F)$ south peak where ROV diving site $\mathrm{F}$ is located

velocity zones beneath BSR. We interpret the high velocity layer above BSR to be a 100-200 m thick gas hydrate bearing layer where $\mathrm{P}$ wave velocity ranges from 1900 to $2100 \pm 100 \mathrm{~m} / \mathrm{s}$, and the low velocity zones beneath BSR to be free gas filling sediments where $\mathrm{P}$ wave velocity lies between 1450 and $1550 \pm 100 \mathrm{~m} / \mathrm{s}$, and their thickness could reach $300 \mathrm{~m}$.

\section{Fluid circulation model}

Seismic investigations have shown that BSR, blanking zone and velocity anomalies are clearly imaged in this environment on the passive China continental slope in the area offshore SW Taiwan. There are indications that methane gases formed in the sediments migrate upward into the ridge, and could form gas hydrates when P-T conditions are met. Besides, buoyancy of free gas mobilized warm fluid flow is also focused toward the crest of the ridge. Under these conditions, gas hydrate should be affected by warm fluid and form as the methane passes in the gas hydrate stability zone. Due to the geometry of the ridge, the base of gas hydrate stability zone forms an elongated half dome shape trapping a large amount of free gases below. If there is a fracture or fault system developed inside the ridge, then it will become a conduit for trapped gas to migrate upward to the seafloor and forms a gas plume or cold seep site.

Furthermore, erosion of the ridge can also affect the possible fluid circulation system. Since the ridges were formed by down-slope canyon erosion processes, the original flat lying or gently dipping strata were truncated by the submarine canyons, if there are high permeable layers in the strata, then cold sea water could easily flow into the interior of the ridge while warm fluid inside the ridge continuously moving upward which form an efficient fluid circulation system (Paull et al. 1991, 1995). These processes could explain the observed geothermal gradient and heat flows around the Formosa Ridge are lower than its nearby area (Chen et al. 2012; Liao et al. 2014). The two dimensional thermal-modeling around Formosa Ridge proposed by Chen et al. (2014) presents temperature reductions along the ridge, but higher geothermal gradients on the flanks and lower gradients under the summit of the ridge. These thermal simulations also suggest that the observed variations in temperature changes and geothermal gradients cannot be explained only by vertically upward fluid migration. In addition, the smoothed temperature field could be the consequence of cold fluid mixing. The gently dipping and probably high permeable layers under the ridge observed in the seismic profiles could provide pathways for cold deep-sea water horizontally diffuse into the ridge. 


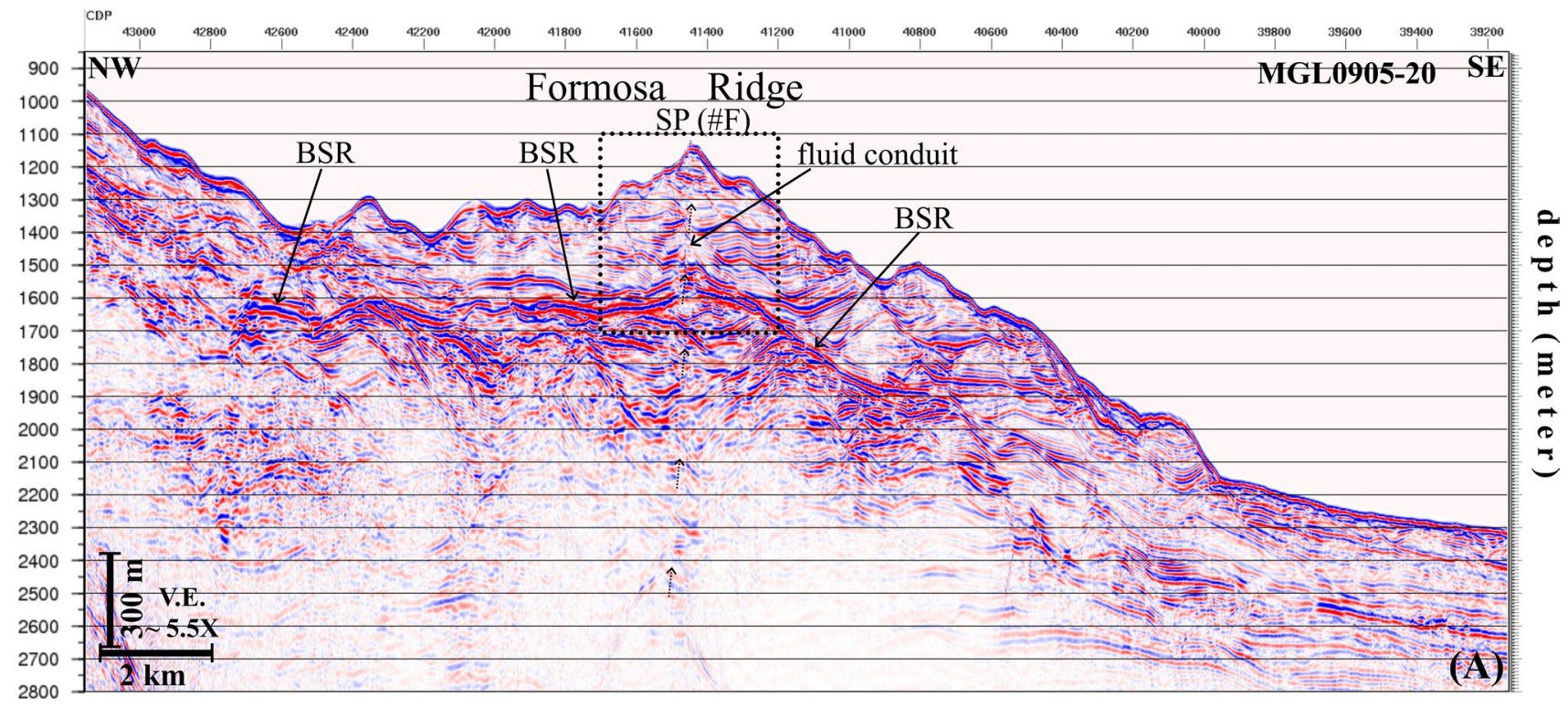

$\operatorname{CDP} 430004280042600424004220042000 \quad 41800 \quad 41600 \quad 4140041200410004080040600 \quad 40400402004000039800 \quad 39600 \quad 39400 \quad 39200$

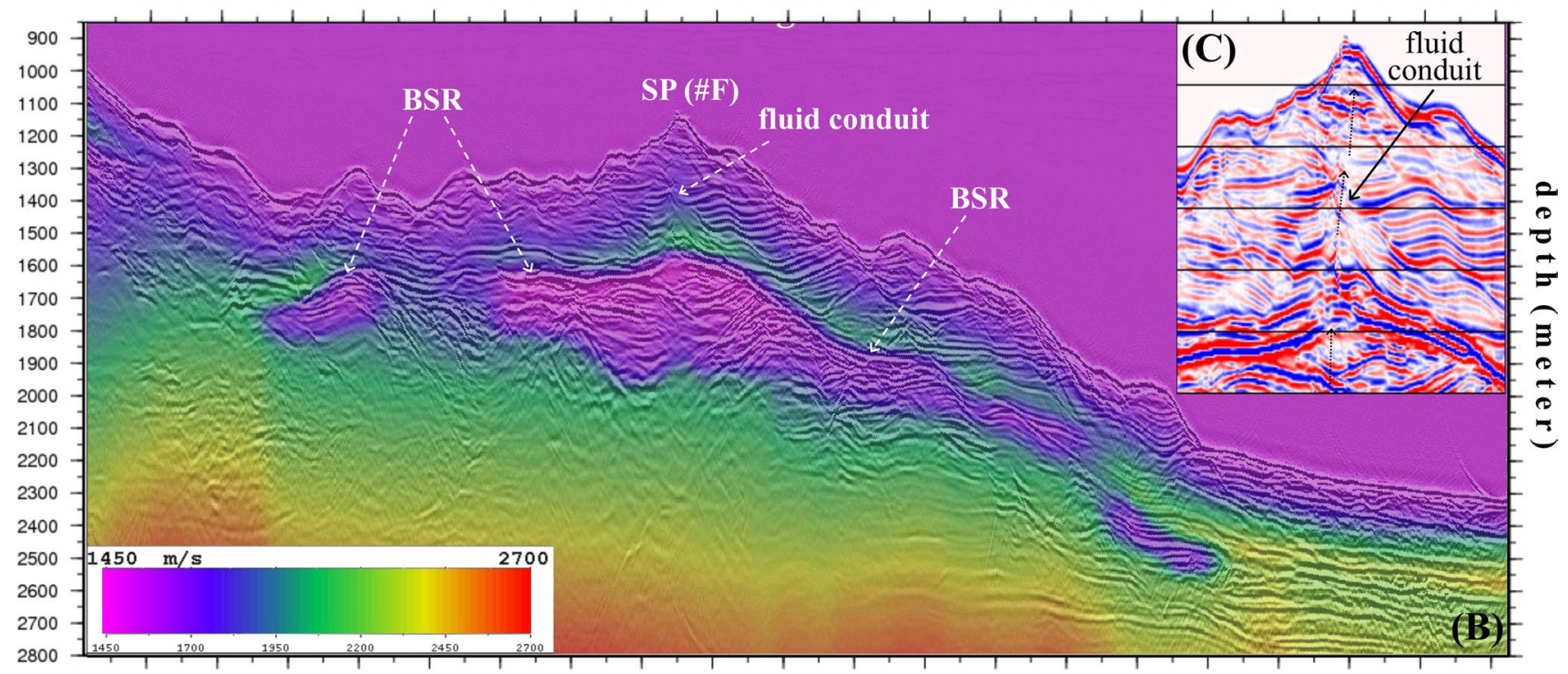

Fig. 11 a Pre-stack depth migration section of seismic reflection profile MGL0905-20. The fluid conduit under the SP (\#F) marked by a blank dotted frame is enlarged in (c). The depth scale is meter. b Velocity model of seismic profile MGL0905-20. See Fig. 4 for pro- file location. $S P(\# F)$ south peak where ROV diving site $\mathrm{F}$ is located. c The inset shows a close-up of the fluid conduit marked by black dashed arrows

into the system from the flank of the ridge, hydrogen sulfide will be produced at the seep when the methane arrives at the seafloor, and the fluid circulation system will output quantities of both methane and hydrogen sulfide, thus creates the unusual chemosynthetic communities dominated by species both in cold seep and in hydrothermal vent environment (Chuang et al. 2010; Feng and Chen 2015; Feng et al. 2015). Comparing the intensive seepage activities due to reduced hydrostatic pressures during the global sea-level fall (Tong et al. 2013; Han et al. 2014; Feng and Chen 2015), the diffusion of cold sea water entering the system from both flanks the seafloor, cold sea water with plenty of sulfate would flow 
of the ridge is a relatively slow process which drives only relatively low intensity of warm gases migrating upward. This scenario could also explain reduced supply of methane and vanishes of chemosynthetic communities on the flanks of the ridge since $2 \mathrm{ka} \mathrm{BP}$ (Feng and Chen 2015).

\section{Conclusion}

A collaborative Taiwan-Japan ROV diving investigation cruise NT07-05 conducted in 2007 offshore SW Taiwan has discovered an active cold seep site existing on top of the Formosa Ridge situated in the passive China continental margin. Both deep-sea mussel Bathymodiolus platifrons and galatheid shrimp Shinkaia crosnieri are vigorously populated at this site, indicating an active vent system dominated by both methane and hydrogen sulfide. By integrating swatch bathymetry, high-resolution single-channel and large-offset deep reflection seismic data, we now have a good understanding on the structural characters and possible fluid migration paths of this cold seep site. The cold seep is situated at the southern peak of the Formosa Ridge which was formed by submarine erosion processes. Submarine canyons that incise continental slope on both sides of the ridge are the controlling factor of the ridge formation. The strata are generally flat lying, but mass wasting processes and developing sediment wave features are observed on the Formosa Ridge and adjacent seafloor. Strong BSR is observed 400-500 ms below the seafloor with many bright reflections beneath the ridge peaks. A well-developed fluid conduit has been observed on all seismic data across the cold seep site. This conduit appears as a vertical blank zone connecting the deep strata below BSR to the southern peak of the ridge. A pre-stack depth migration section shows that this fluid conduit extends about $1.5 \mathrm{~km}$ from the crest of the ridge down to the deep strata below BSR.

A fluid circulation model is proposed to explain why the chemosynthetic communities at the cold seep site on top of the Formosa Ridge are dominated by the species often observed in the hydrothermal vent environment. Well-developed BSRs are widely distributed beneath the seafloor of the slope ridges. The geometry of the ridge and the shape of the base of the gas hydrate stability zone enable gas to be trapped beneath the ridge crest, and this "gas reservoir" is shallower than the surrounding canyon floors on either side of the ridge. We suggest that this "ridge type" gas reservoir configuration enables the cold sea water from the flanks of the Formosa Ridge to flow into this fluid system; moreover, an effective fluid circulation system is developed which emits large amount of both hydrogen sulfide and methane that can feed the unusual chemosynthetic communities observed at the cold seep site.
Acknowledgements We would like to thank Chao-Chung Lin, Yunshuan Wang, and San-Hsiung Chung of the Central Geologic Survey, Taiwan for their supports to the Taiwan gas hydrate investigation program. The captains, crew and technical personnel onboard the R/Vs Ocean Researcher I, Natsushima and Marcus G. Langseth are appreciated for their efforts in collecting the seismic data used in this study. The cruise NT07-05 was supported by JAMESTEC of Japan and the research work on the Taiwan side was funded by the National Science Council (now the Ministry of Science and Technology) of Taiwan and the Central Geological Survey, Ministry of Economic Affairs, Taiwan. Constructive comments and suggestions from Charles Paull and two other anonymous reviewers improved this paper greatly. The authors are grateful to late Prof. Tsanyao F. Yang for great teamwork on the cruise NT07-05, and this paper is dedicated to him, our memorable colleague.

Open Access This article is distributed under the terms of the Creative Commons Attribution 4.0 International License (http://creativecommons.org/licenses/by/4.0/), which permits unrestricted use, distribution, and reproduction in any medium, provided you give appropriate credit to the original author(s) and the source, provide a link to the Creative Commons license, and indicate if changes were made.

\section{References}

Berndt C (2013) RV SONNE Fahrtbericht/Cruise report SO227 TAIFLUX: fluid and gas migration in the transition from a passive to an active continental margin off SW Taiwan, Kaohsiung-Kaohsiung, 02.04-02.05.2013

Berndt C, Crutchley G, Klaucke I, Jegen M, Lebas E, Muff S, Lieser K, Roth T, Chi WC, Feseker T (2014) Geological controls on the gas hydrate system of Formosa Ridge, South China Sea, OCEANS'14 MTS/IEEE conference, pp 1-4, Taipei, 7-10 April

Borowski WS, Paull CK, Ussler W (1999) Global and local variations of interstitial sulfate gradients in deep-water, continental margin sediments: sensitivity to underlying methane and gas hydrates. Mar Geol 159:131-154

Chen L, Chi WC, Liu CS, Shyu CT, Wang Y, Lu CY (2012) Deriving regional vertical fluid migration rates offshore southwestern Taiwan using bottom-simulating reflectors. Mar Geophys Res 33:379-388

Chen L, Chi WC, Wu SK, Liu CS, Shyu CT, Wang Y, Lu CY (2014) Two dimensional fluid flow models at two gas hydrate sites offshore southwestern Taiwan. J Asian Earth Sci 92:245-253

Chiu JK, Tseng WH, Liu CS (2006) Distribution of gassy sediments and mud volcanoes offshore southwestern Taiwan. Terr Atmos Ocean Sci 17:703-722

Chuang PC, Yang TF, Lin S, Lee HF, Lan TF, Hong WL, Liu CS, Chen JC, Wang Y (2006) Extremely high methane concentration in bottom water and cored samples from offshore southwestern Taiwan. Terr Atmos Ocean Sci 17:903-920

Chuang PC, Yang TF, Hong WL, Lin S, Sun CH, Lin AT, Chen JC, Wang Y, Chung SH (2010) Estimation of methane flux offshore SW Taiwan and the influence of tectonics on gas hydrate accumulation. Geofluids 10:497-510

Chuang PC, Dale AW, Wallmann K, Haeckel M, Yang TF, Chen NC, Chen HC, Chen HW, Lin S, Sun CH, You CF, Horng CS, Wang Y, Chung SH (2013) Relating sulfate and methane dynamics to geology: the accretionary prism offshore SW Taiwan. Geochem Geophys Geosyst 14:2523-2545 
Feng D, Chen D (2015) Authigenic carbonates from an active cold seep of the northern South China Sea: new insights into fluid sources and past seepage activity. Deep Sea Res Part II 122:74-83

Feng D, Cheng M, Kiel S, Qiu JW, Yang Q, Zhou H, Peng Y, Chen D (2015) Using Bathymodiolus tissue stable carbon, nitrogen and sulfur isotopes to infer biogeochemical process at a cold seep in the South China Sea. Deep Sea Res Part I 104:52-59

Fujikura K, Tsuchida S, Nunoura T, Soh W, Machiyama H, Huang C, Lin S (2007) Vent-type chemosynthetic community associated with methane seep at the Formosa Ridge, off southwest Taiwan. In: Proceedings of the international conference on gas hydrate: energy, climate and environment, Taipei, 4-5 Oct

Guan H, Feng D, Wu N, Chen D (2016) Methane seepage intensities traced by biomarker patterns in authigenic carbonates from the South China Sea. Org Geochem 91:109-119

Han X, Suess E, Liebetrau V, Eisenhauer A, Huang Y (2014) Past methane release events and environmental conditions at the upper continental slope of the South China Sea: constraints by seep carbonates. Int J Earth Sci 103:1873-1887

Hsu HH, Liu CS, Yu HS, Chang JH, Chen SC (2013) Sediment dispersal and accumulation in tectonic accommodation across the Gaoping Slope, offshore Southwestern Taiwan. J Asian Earth Sci 69:26-38

Huang CY, Chien CW, Zhao MX, Li HC, Iizuka Y (2006) Geological study of active cold seeps in the syn-collision accretionary prism Kaoping slope off SW Taiwan. Terr Atmos Ocean Sci 17:679-702

JAMSTEC and TNCOR (2007) Flux and composition of fluid associated with mud volcano and fault activity off SW Taiwan. Cruise report on R/V Natsushima NT07-05. Cruise, 16-13 Mar 2007

Klaucke I, Berndt C, Crutchley G, Chi WC, Lin S, Muff S (2016) Fluid venting and seepage at accretionary ridges: the four way closure ridge offshore SW Taiwan. Geo Mar Lett 36:165-174

Liao WZ, Lin AT, Liu CS, Oung JN, Wang Y (2014) Heat flow in the rifted continental margin of the South China Sea near Taiwan and its tectonic implications. J Asian Earth Sci 92:233-244

Lim YC, Lin S, Yang TF, Chen YG, Liu CS (2011) Variations of methane induced pyrite formation in the accretionary wedge sediments offshore southwestern Taiwan. Mar Pet Geol 28:1829-1837

Lin S, Hsieh WC, Lim Y, Yang T, Liu CS, Wang Y (2006) Methane migration and its influence on sulfate reduction in the Good Weather Ridge region, South China Sea continental margin sediments. Terr Atmos Ocean Sci 17:883-902

Lin S, Lim YC, Liu CS, Yang TF, Chen YG, Machiyama H, Soh W, Fujikura K (2007a) Formosa Ridge, a cold seep with densely populated chemosynthetic community in the passive margin, southwest of Taiwan. Geochim Cosmochim Acta 71(Supplement 1):A582

Lin S, Machiyama H, Chen YG, Soh W, Yang TF, Wang Y, Lim YC (2007b) Near sea floor gas hydrate formation and influence on pore water chemistry and authigenic carbonate at the Formosa Ridge, south China sea. EOS Trans AGU 88(52):OS21A-05

Lin AT, Liu CS, Lin CC, Schnurle P, Chen GY, Liao WZ, Teng LS, Chuang HR, Wu MS (2008) Tectonic features associated with the overriding of an accretionary wedge on top of a rifted continental margin: an example from Taiwan. Mar Geol 255:186-203

Lin AT, Yao B, Hsu SK, Liu CS, Huang CY (2009a) Tectonic features of the incipient arc-continent collision zone of Taiwan: implications for seismicity. Tectonophysics 479:28-42

Lin CC, Lin AT, Liu CS, Chen GY, Liao WZ, Schnurle P (2009b) Geological controls on BSR occurrences in the incipient arc-continent collision zone offshore southwest Taiwan. Mar Pet Geol 26:1118-1131

Lin AT, Lin CC, Liu CS, Liao WZ, Lin SL, Yang TF, Shyu CT, Hsu SK, Wang TK, Wang Y (2011) Gas-hydrate petroleum systems, play types and prospects in an accretionary wedge and its adjacent rifted continental margin, Taiwan. In: 7th international conference on gas hydrates, Edinburgh, 17-21 Jul

Liu CS, Huang IL, Teng LS (1997) Structural features off southwestern Taiwan. Mar Geol 137:305-319

Liu CS, Deffontaines B, Lu CY, Lallemand S (2004) Deformation patterns of an accretionary wedge in the transition zone from subduction to collision offshore southwestern Taiwan. Mar Geophys Res 25:123-137

Liu CS, Schnurle P, Wang Y, Chung SH, Chen SC, Hsiuan TH (2006) Distribution and characters of gas hydrate offshore southwestern Taiwan. Terr Atmos Ocean Sci 17:615-644

Liu CS, Morita S, Liao YH, Ku CY, Machiyama H, Lin S, Soh W (2008) High-resolution seismic images of the Formosa Ridge off southwestern Taiwan where "hydrothermal" chemosynthetic community is present at a cold seep site. In: Proceedings of the 6th international conference on gas hydrates (ICGH 2008) Vancouver, British Columbia

Machiyama H, Lin S, Fujikura K, Huang CY, Ku CY, Lin LH, Liu CS, Morita S, Nunoura T, Soh W, Toki T, Yang TF (2007) Discovery of "hydrothermal" chemosynthetic community in a cold seep environment, Formosa Ridge: seafloor observation results from first ROV cruise, off southwestern Taiwan. EOS Trans AGU 88(52), OS23A-1041

Matsumoto R, Ryu BJ, Lee SR, Lin S, Wu S, Sain K, Pecher I, Riedel M (2011) Occurrence and exploration of gas hydrate in the marginal seas and continental margin of the Asia and Oceania region. Mar Pet Geol 28:1751-1767

Morita S, Liu CS, Ku CY, Machiyama H, Lin S, Soh W, Shimizu $S$ (2009) Fluid circulation in a region of submarine mounds off Southwest Taiwan: high-resolution seismic records from the continental slope ridge. J Geogr 118(3):424-434 (in Japanese with English abstract).

Paull CK, Chanton J, Martens C, Fullagar P, Neumann A, Coston J (1991) Seawater circulation through the flank of the Florida platform: evidence and implications. Mar Geol 102:265-279

Paull CK, Fullagar PD, Bralower TJ, Röhl U (1995) Seawater ventilation of mid-Pacific Guyots drilled on ODP Leg 143. In: Proceedings of the ocean drilling program, Scientific Results, vol 143, pp 231-241

Suess E, Huang Y, Wu N, Han X, Su X (2005) South China Sea continental margin: geological methane budget and environmental effects of methane emissions and gas hydrates. RV SONNE Cruise Rep 177:1-154

Swidinsky A, Sommer M, Hölz S, Jegen M, Berndt C, Chi WC (2014) Electromagnetic imaging of gas hydrate deposits off-shore Taiwan: first results of the Taiflux survey. SEG Tech Prog Expand Abstr 2014:760-764

Tong H, Feng D, Cheng H, Yang S, Wang H, Min AG, Edwards RL, Chen Z, Chen D (2013) Authigenic carbonates from seeps on the northern continental slope of the South China Sea: new insights into fluid sources and geochronology. Mar Pet Geol 43:260-271

Wang Y, Liu CS (2009) Gas hydrate investigation in Taiwan. Fire in the Ice, Methane hydrate newsletter, Winter 2009, NETL, pp 15-17

Yang TF, Yeh GH, Fu CC, Wang CC, Lan TF, Lee HF, Chen CH, Walia V, Sung QC (2004) Composition and exhalation flux of gases from mud volcanoes in Taiwan. Environ Geol 46:1003-1011

Yang TF, Chuang PC, Lin S, Chen JC, Wang Y, Chung SH (2006) Methane venting in gas hydrate potential area offshore of SW Taiwan: evidence of gas analysis of water column samples. Terr Atmos Ocean Sci 17:933-950

Yang CH, Tsuchida S, Fujikura K, Fujiwara Y, Kawato M, Chan TY (2016) Connectivity of the squat lobsters Shinkaia crosnieri (Crustacea: Decapoda: Galatheidae) between cold seep and hydrothermal vent habitats. Bull Mar Sci 92:17-31 